\title{
KNOWLEDGE, FACILITIES, AND THEIR ASSOCIATIONS WITH NURSE ADHERENCE TO HAND HYGIENE AT SUBULUSSALAM HOSPITAL, ACEH
}

\author{
Erman Suryadi, Zulfendri, Destanul Aulia
}

\author{
Masters Program in Public Health, Universitas Sumatera Utara
}

\begin{abstract}
Background: Nosocomial infections are the main problems rising morbidity and mortality in health care settings. Effective hand hygiene practices in hospitals plays a key role in improving patient and provider safety. Hand hygiene is the most effective method for preventing these infections. This study aimed to analyze the associations of knowledge and hospital facilities with adherence to hand hygiene among nurses at Subulussalam Hospital, Aceh.

Subjects and Methods: This was a cross sectional study conducted at Subulussalam Hospital, Aceh. A sample of 64 nurses were selected for this study by exhaustive sampling. The dependent variable was adherence to hand hygiene. The independent variables were knowledge and hospital facilities. The data were collected by questionnaire and analyzed by a multiple logistic regression.

Results: Nurses adherence to hand hygiene was associated with better knowledge $(\mathrm{OR}=1.80 ; 95 \% \mathrm{CI}=1.55$ to $3.01 ; \mathrm{p}=0.033)$ and facilities $(\mathrm{OR}=2.10 ; 95 \% \mathrm{CI}=1.40$ to $4.77 ; \mathrm{p}=0.049$ ).

Conclusion: Nurses adherence to hand hygine is associated with knowledge and facilities.

Keywords: knowledge, facilities, hand hygine

\section{Correspondence:}

Erman Suryadi. Masters Program in Public Health, Universitas Sumatera Utara, Medan, North Sumatera. Email: salamsuryadi@yahoo.com.

Mobile:+62 81536760473 .
\end{abstract}

